\title{
Benedetto Bacchini and the "Progetto ai letterati d'Italia" of Giovannartico di Porcìa
}

\author{
Jordan Lancaster
}

In 1728 , the "Progetto ai letterati d'Italia" was published in the pages of the Raccolta d'opuscoli scientifici e filologici edited by Angelo Calogerà. The author of this manifesto, the nobleman Giovannartico di Porcìa, presented contemporary intellectuals with the concept of a new project for literary historiography, the compilation of an encyclopedia of the intellectual autobiographies of the major protagonists of early Settecento letters and culture. Much attention has been paid to this document because of its relationship to the autobiography of Giambattista Vico which was actually published together with the "progetto" as its ideal contribution. But Vico was not the only supporter of Porcia whose intellectual autobiography was published. Despite the fact that the intended volume was never completed, several "vite" appeared in various books and journals. One in particular has been neglected by scholars, that written by Benedetto Bacchini. This little known text merits study both for its relationship to Porcia's project for intellectual autobiography and for an understanding of its place in the Italian autobiographical canon in a crucial moment for the history of ideas in Italy, the "éveil de l'esprit philosophique."

Benedetto Bacchini (1651-1721) of Parma was a cleric and scholar, librarian to Rinaldo I d'Este. He edited the Liber pontificalis of Agnello Ravennate (1708) and was the author of a history of the monastery of Polirone and a treatise, De ecclesiasticae hierarchiae originibus (1703), also founding and directing an important Giornale de' letterati in Parma and Modena from 1686 to 1697. Moreover, he is considered the most significant transition figure between baroque erudition and the new Italian culture for his role as the "maestro" of Ludovico Antonio Muratori and Scipione Maffei. Muratori describes him as follows:

Mancava a me ed io desiderava forte di trovare chi porgesse buon filo a' miei passi nello studio dell'erudizione; e senza che facessi gran viaggio, Modena stessa mel somministro, quale non si sarebbe incontrato in assaissime altre citta, anche delle più riguardevoli. Fu questi il p. don Benedetto Bacchini, monaco casinese, altamente stimato e protetto dalla serenissima casa d'Este, poscia bibliotecario del mio padron serenissimo dopo la morte di Iacopo Cantelli e finalmente abate di S. Pietro di Modena. Dirò in poche parole: per l'ampiezza dell'erudizione e per l'ottimo 
gusto in ogni sorta di letteratura era eccellente uomo il p. Bacchini e tale che pochi suoi pari potea mostrare l'Italia; di modo che troppa perdita hanno fatto le lettere a Modena in avere quest'anno 1721 perduto un valentuomo di tanto sapere e grido. (13-14)

The Italian Settecento is known as a "secolo autobiografico" and indeed, Bacchini's "vita," published in 1729 in the Giornale de' letterati d'Italia, forms an important part of the corpus. In order first to understand its relationship to Porcìa's ideals for intellectual autobiography, let us examine the "progetto."

Giovannartico di Porcia's project was devised with the view to forming a collection of autobiographies of the leading intellectuals of the day. Its intentions were both of a didactic and an historiographic nature. He solicited "vite" from such prominent figures as Muratori, Vico, Apostolo Zeno, Antonio Vallisnieri, Pierjacopo Martello and others. Porcia provided these scholars with guidelines in his proposal, the "Progetto ai letterati d'Italia." Porcia is very specific in his request which is formulated almost as precisely as a questionnaire strictly limited to intellectual life. He asks that the writer describe the method of his studies, first at school then at the university, then in independent research. He should denounce errors in methodology and emphasize the positive aspects of learning. Having thus discussed his formation and his intellectual approach, the writer then must continue analyzing the genesis of his greatest works together with the present state of his research:

Quest'Istoria dovrà, siccome testé s'è per noi accennato, da essi stessi scriversi contezza in essa dando del tempo della loro nascita, del nome de' loro Padri, e della loro Patria, e di tutte quelle avventure della loro vita, che render la ponno più ammirabile, e più curiosa, e che onestamente da essi senza carico del loro buon nome, e senza pena d'un giusto rossore puote al Mondo, ed ai posteri comunicarsi. Appresso o separatamente raccontando, o intrecciando, secondo occasione, o secondo lor genio, alle accennate notizie quelle de' loro Studi, una più distinta narrazione verran descrivendo di questi, stendendola con le più esatte circostanze, e minute. (132)

The writer is also asked to relate the authors and the methods most important for his intellectual formation. The autobiographical pact of sincerity is already present as an integral part of the new genre:

Qui è dove ricercasi tutta la sincerità de' nostri Letterati, a' quali in questo punto auguriamo un'eroica indifferenza ad ammaestramento di chi non sente molto avanti nel buon gusto, ed è questo quel punto, a cui come a bersaglio s'indirizza questa nostra fatica. Qui è dove li preghiamo a svilupparsi dalle catene dell'amor proprio, e sciolti da ogni privata passione dichiararsi per lo bene pubblico, la piccola gloria di far illustri solamente se stessi posponendo alla vera, e grande di giovare a una intera Nazione. (136)

The goal of the project is the preparation by the best contributors in various 
fields of one volume as an encyclopedia of facts and culture for the edification of all readers, particularly students.

Also inherent in this ideal model of intellectual autobiography presented by Porcia is the final objective of cultural reform. The latter points clearly to an intent altogether anti-Aristotelian, anti-traditional and anti-scholastic. "La querelle des anciens et des modernes" leads to a progressive view of history in which the new age is considered more advanced than the generations which preceded it, thereby anticipating one of the fundamental tenets of the Enlightenment. Criticism of the Jesuit system of education by illustrious men of learning brings them to speak naturally of themselves, of their institutional formation and of their auto-didacticism. In this sense, the project represents a moment of crisis in the world of learning and witnesses the daybreak of a new age, indicated in the birth and affirmation of a new literary genre, that of intellectual autobiography.

The "Progetto ai letterati d'Italia" was published together with the preliminary version of Giambattista Vico's Vita scritta da se medesimo. The Neapolitan philosopher and historian's innovation of precise ideas on the emerging genre of intellectual autobiography, and their implementation, were recognized at once by Porcia, who decided to publish Vico's Vita following the "Progetto" as an example of the ideal response to his invitations:

[La] . . Vita del Sig. D. Gio: Battista de Vico celebre Letterato Napoletano da lui stesso descritta, e che più dell'altre, che fin ad ora ci son pervenute, s'accosta all' $i$ dea da noi conceputa. Ella questa Vita potrà in parte servire di norma a chi vorrà favorire la nostra Raccolta, e che la cortesia imitando, e insieme la maniera nello stendere le notizie de' propri studj del Sig. de Vico darà mano al compimento di questa utile fatica. (140)

Vico's Vita was viewed by Porcìa as an ideal model and later became a paradigm for the entire corpus of contemporary intellectual autobiography in Italy. The account is chronological with foreshortened attention drawn to the years of maturity. The narration begins following the tenets established by Quintillian for autobiography and continues with a third person account, largely streamlined and focusing purely on the intellectual development of the author-narrator-protagonist. There are few descriptive passages or spatial representations in the text. The narrative is implicitly coherent with the political nature of Porcia's proposal in various references to the solitude and alienation of the author-narrator-protagonist and his place with reference to the new movements in European culture. These are the aspects which caused Porcia's favourable critique.

One year later, in another journal published in Venice, Benedetto Bacchini's autobiography also appeared. Like the Vichian work, it embodies many of the same features so favourably reviewed by the author of the "progetto," thereby confirming the close relationship between these works. Let us now examine first the relationship between Porcia and Bacchini before turning to a close reading of the work itself as a realization of the ideals of the project, not unlike Vico's own 
autobiography.

Porcìa states explicitly his relationship to Bacchini in the text of the "Progetto ai letterati d'Italia." He describes the late cleric's encouragement many years previously: "Grand'eccitamento ci diede pure a non pentirci di questo nostro pensiero il P. Abate D. Benedetto Bacchini della nobilissima Congregazione Cassinese, uomo di venerabile ricordanza ... . Egli sin l'anno 1720 in Padova ci confortò all'impresa ..." (141-42). Porcì goes on to mention, almost en passant, that Bacchini had promised to cooperate with the endeavour: ". . . e ci promise oltre la Storia di se stesso, e de' studj suoi, quella d'altri Dotti Amici” (142). The only "vita" left to us by Bacchini is published posthumously in the Giornale de' letterati d'Italia in $1729 .{ }^{1}$ Although intense interest has been paid by scholars to the "Progetto ai letterati d'Italia," this text has been completely neglected, despite its obvious adherence to Porcìa's ideals.

The autobiography dates from 1705 when it was originally prepared for the third volume of Giacinto Gimma's Elogi degli uomini illustri dell'accademia Rossanese. It first saw publication, however, in the Giornale de' letterati d'Italia, where it is briefly presented with an anonymous introduction:

Dovendo noi qui registrare notizie esatte della vita del Padre Abate Don Benedetto Bacchini, morto il dì 11 di settembre del 1722 giudichiamo di non potersi dare migliori di quelle che lo stesso chiarissimo Padre scrisse di se medesimo, e nel principio dell'anno 1705 mandò a Bari al Sig. Abate Giacinto Gimma, per inserirle nel tomo III degli Elogi degli uomini illustri dell'accademia Rossanese, alla qual accademia fu il Padre Abate Bacchini, vivendo, ascritto, e della quale il suddetto Sig. Abate Gimma e Promotor generale. Queste notizie son dettate latinamente, in istile semplice e schietto; e ben si meritano d'esser pubblicate per le stampe, acciocché né pure quest'operetta di sł illustre scrittore venga a perire; e insieme si serbi, per quanto da noi dipende eterna del medesimo la memoria. (Bacchini 295-96)

In describing the work, the anonymous narrator underscores stylistic considerations. Written in Latin, Bacchini's prose is "in istile semplice e schietto," following the guidelines of sober, anti-baroque poetics. The choice of Latin not only confers on the autobiography a sense of seriousness in line with the scholarly nature of the content, but also makes the text accessible to other European scholars and underscores links to the classical tradition of life narrative. The text begins as the Venetian count had instructed, with an account of Bacchini's birthdate, birthplace and parents in the style established by Quintillian:

Bernardinus Bacchinius natus est anno 1651 die ultima augusti, hora sere decima in civitate Burgi sancti Domnini [sic], ibique in cathedrali ecclesia baptizatus. Patrem habuit Alexandrum Bernardini filium, matrem Johannam Martiniam, Parmensem, adhuc hoc anno 1705 superstitem. (Bacchini 296)

The chronological narrative is almost immediately foreshortened as the authornarrator-protagonist jumps ahead sixteen years to his entry in religious orders. 
The narrative proceeds year by year with the description of the intellectual aspects of Bacchini's life as a monk. He corresponds with many of the greatest thinkers and "letterati" of his day. Of course, Bacchini is not a sinner of pride and he never draws excess attention to his deeds. Yet all of the illustrious men he meets are portrayed as paying him great respect: "Dum Florentiae degit, cum Antonio Magliabequio in tota literatorum republica celeberrimo, amicitias contraxit" (302). Inverted praise is a literary feature to be found also in Vico's Vita and indeed throughout the corpus of early Settecento autobiography. Battistini explains the motivation for this technique in the cultural context of the age. To speak of one's own self or to sing one's own praises is an act of pride in the climate of the enormous power of the Inquisition in post-Counter-Reformation Italy. The only possible motivations acceptable were either of a didactic or of an apologetic nature (Vico 1242). Thus the very act of autobiography was frowned upon. Early writers of the genre used a special rhetoric to tell their own life stories without being accused of pride. Such is the explanation for many features common to contemporary "vite." Compliments are inserted in the speeches of illustrious men, a didactic intent is emphasized, the third person narrative deflects vestiges of subjectivity. This rhetoric is used by Bacchini throughout the autobiography.

Despite a streamlined account of Bacchini's studies and friendships, there is implicit acknowledgement of his place in contemporary literary circles. His role as the teacher of Maffei and Muratori underscores his place in the development of the new cultural trends in Italy. He was thus a part of the same movement for reform as was Porcìa with regard to the "querelle des anciens et des modernes." Like Vico, he was predisposed to Porcì's agenda for cultural change and the implicit anti-scholasticism and anti-Aristotelianism is made relevant within the context of the "éveil de l'esprit philosophique." Formal considerations lead us to assert that both Bacchini and Vico were aware of working within the coordinates of an emerging genre. As outlined above, it appears evident that both authors attempted to forge a contemporary response to Porcìa's invitation for intellectual autobiography by creating a fusion of the related traditions of hagiography, biography and classical memoirs.

Bacchini's relationship with Porcia was twofold: he was both an advisor during the formation and articulation of the project for intellectual autobiography and author of a work which adhered fully to those ideals. It is a coincidence of literary history that his own autobiography and the "Progetto ai letterati d'Italia" were published within a year of each other. As much as the more famous Vita scritta da se medesimo of Giambattista Vico, Bacchini's text can be considered to conform to the ideals of Porcia, thereby underscoring the general trends of contemporary culture.

Istituto italiano per gli studi storici, Napoli 


\section{NOTE}

1 A philological note concerning the publication of this work in the Giornale de' letterati d'Italia: due to a typographer's error in the pagination of the index, the text is extremely difficult to locate. It is to be found between pages 295-319.

\section{WORKS CITED}

Bacchini, Benedetto. "Vita." Giornale de' letterati d'Italia 2 (1729): 295-319.

Battistini, Andrea. Lo specchio di Dedalo. Bologna: Il Mulino, 1990.

De Michelis, Cesare, and Gilberto Pizzamiglio, eds. Vico e Venezia. Firenze: Olschki, 1982.

Muratori, Lodovico Antonio. "Intorno al metodo seguito ne' suoi studi. Lettera all'illustrissimo signore Giovanni Artico conte di Porcia." Opere. Ed. Giorgio Falco and Fiorenzo Forti. Vol. 1. Milano-Napoli: Ricciardi, 1964. 6-38.

Porcia, Giovannartico di. "Progetto ai letterati d'Italia per scrivere le loro vite." Raccolta d' opuscoli scientifici e filologici 1 (1728): 129-43.

Quintillian. Istitutio Oratoria. Ed. Harold Edgeworth Butler. Cambridge: Harvard UP, 1963.

Vico, Giambattista. Opere. Ed. Andrea Battistini. Milano: Mondadori, 1990. 